\title{
PENGEMBANGAN LEMBAR KERJA SISWA (LKS) BERBASIS PREDICT OBSERVE EXPLAIN MATERI SISTEM PENCERNAAN DAN PERNAPASAN PADA MANUSIA DI KELAS XI SMA
}

\author{
Suprianto Try Andi Ama ${ }^{1}$, Mistianah ${ }^{2}$ \\ Program Studi Pendidikan Biologi FPIEK IKIP Budi Utomo Malang \\ e-mail : andiama46@gmail.com
}

\begin{abstract}
This study aims to: (1) develop Student Worksheets (LKS) based on the Predict Observe Explain Model for Class XI High School and (2) find out the feasibility test of Student Worksheets (LKS) based on the Predict Observe Explain model on the digestive system and respiratory system material in human. This research was development research (research and development) with the 4D model (Define, Design, Develop, and Disseminate). This research was conducted in March 2018 until July 2018 at IKIP BUDI UTOMO Malang. Data of feasibility tests was analyzed with descriptive analysis. The results of this study were: (1) the development of Student Worksheets (LKS) based on the Predict Observe Explain (POE) model produces a pre-filled section containing the main title page, preface, table of contents, competency map and instructions for use, the contents of the digestive system material and the human respiratory system and practice questions, the post-contents section contains a bibliography and author's profile with a total of 62 pages using 70 grams of HVS paper to fill the LKS and AP 120 paper for the cover of the LKS, printed with A5 paper size, (2) the results of the feasibility assessment by material experts get an average number of scores of 41.5 with a mean score of 3.4 which includes eligible criteria. Feasibility assessment of media experts get an average score of 43 with a mean score of 3.3 which includes eligible criteria so that LKS based on the Explain Predict Observe model is suitable for use as teaching material.
\end{abstract}

Keywords: Lembar Kerja Siswa (LKS), Model Predict Observe Explain

\section{PENDAHULUAN}

Pendidikan merupakan faktor utama dalam meningkatkan sumber daya manusia, dan mengembangkan bakat, minat dan kemampuan siswa secara optimal. Hal tersebut sesuai dengan fungsi dan tujuan pendidikan. Di Indonesia pendidikan telah diatur dalam undang-undang RI No. 20 Tahun 2003 tentang Sistem Pendidikan Nasional.

Pembelajaran merupakan bentuk kegiatan guru secara terprogram dalam desain instruksional, untuk membuat siswa belajar aktif, dan menekankan pada penyediaan sumber belajar (Dimyati dan Mudjiono, 1999). Dalam proses pembelajaran keaktifan siswa adalah hal utama yang diharapkan oleh guru namun yang sering terjadi adalah sebaliknya faktanya siswa kurang aktif dalam proses pembelajaran, banyak faktor yang mempengaruhi diantaranya; siswa kurang fokus dan cara penyampaian pembelajaran yang dilakukan oleh guru kurang tepat dengan materi yang diajarkan sehingga siswa mengalami kesulitan dalam hal meningkatkan motivasi dan hasil belajar kognitif siswa, faktor tersebut menjadi 
masalah utama bagi guru. Motivasi dan hasil belajar kognitif merupakan aspek penting dalam pembelajaran. Salah satu cara untuk meningkatkan motivasi siswa yaitu dengan mengembangakan lembar kerja siswa yang menarik dan dapat mendorong motivasi dan keaktivan siswa.

$$
\text { Lembar Kerja Siswa (LKS) }
$$

merupakan bahan ajar cetak yang berisi materi, ringkasan dan petunjuk-petunjuk pelaksanaan dalam tugas pembelajaran yang harus dikerjakan oleh siswa. LKS harus mengacu pada kompetensi dasar yang harus dicapai oleh siswa (Prastowo 2011). LKS merupakan lembar kerja yang dibagikan kepada siswa di dalam kelas, agar siswa melakukan kegiatan belajar sesuai petunjuk dalam lembar kegiatan tersebut. Lembar Kerja Siswa yang biasa digunakan saat ini biasanya kurang atau tidak menggunakan model pembelajaran tertentu, salah satu model yang dapat mengembangkan motivasi dan keaktivan siswa adalah model pembelajaran POE (Predict Observe Explain).

Lembar kerja siswa (LKS) berbasis model Predict Observe Explain memberikan proses pembelajaran yang efektif dan inovatif dalam menggali kemampuan siswa baik secara individu maupun dalam kelompok. Langkah-langkah model Predict Observe Explain dapat membangkitkan semangat belajar siswa, sehingga sangat tepat di padukan dalam pembuatan LKS sebagai bahan ajar untuk menunjang proses pembelajaran disekolah. Berdasarkan hasil observasi peneliti pada SMA Negeri 1 Wewewa Timur bahan ajar yang digunakan berupa buku panduan pelajaran Biologi, Buku Siswa Biologi dan LKS. Lembar kerja siswa (LKS) yang digunakan di SMA Negeri 1 Wewewa Timur masih kurang menarik dan kurang menggali kemampuan siswa, sehingga membuat siswa kurang aktif dalam proses pembelajaran. Hal tersebut dikarenakan LKS tidak mengunakan modelmodel tertentu dengan langkah-langkah pembelajaran yang jelas, biasanya hanya berupa kumpulan soal saja. Berdasarkan latar belakang tersebut maka dilakukan penelitian pengembangan LKS berbasis model pembelajaran POE.

\section{METODE PENELITIAN}

Penelitian ini termasuk dalam penelitian pengembangan. Model pengembangan yang digunakan dalam penelitian ini adalah model 4-D (Four D). Model 4D dikembangkan oleh S. Thiagarajan, Dorothy S. Semmel, dan Melvyn I. Semmel (1974). Model pengembangan 4D terdiri dari 4 langkah yaitu: Define, Design, Develop dan Disseminate. Model pengembangan tersebut dipilih dengan alasan karena bertujuan untuk menghasilkan produk berupa LKS.

Produk yang dikembangkan

kemudian diuji kelayakannya melalui proses validasi oleh para ahli atau validator. Validasi dilakukan untuk mengetahui sejauh mana kelayakan LKS berbasis Predict Observe Explain pada materi sistem pencernaan dan sistem pernapasan.

Dalam pengembangan Lembar Kerja Siswa (LKS) berbasis model POE sebagai bahan ajar ini, sumber data yang digunakan melibatkan beberapa orang sebagai validator. Validator tersebut terdiri dari validator ahli materi, validator ahli media dan responden. Adapun data tersebut disajikan pada tabel berikut:

Tabel 1. Validator

\begin{tabular}{lll}
\hline $\begin{array}{l}\text { Tahapan } \\
\text { penelitian }\end{array}$ & \multicolumn{1}{c}{$\begin{array}{l}\text { Sumber } \\
\text { data }\end{array}$} & Jumlah \\
\hline $\begin{array}{l}\text { Validasi } \\
\text { materi }\end{array}$ & ahli Dosen & 1 Orang \\
\hline $\begin{array}{l}\text { Validasi } \\
\text { media }\end{array}$ & ahli Dosen & 1 Orang \\
\hline
\end{tabular}


Teknik analisis data dalam penelitian ini adalah teknik analisis deskriptif. Analisis data yang diperoleh dari angket uji validasi para ahli digunakan untuk mengetahui kelayakan lembar kerja siswa (LKS) berbasis model POE yang dibuat. Angket yang digunakan dalam penelitian ini menggunakan ruubrik dengan skala likert yang berperingkat 1-4 untuk memperoleh pendapat dari validasi para ahli, dengan kriteria " Sangat Layak (SL), Layak (L), Tidak Layak (TL), dan Sangat Tidak layak (STL)". Skor setiap alternatif jawaban yang diberikan oleh responden pada pernyataan Tabel 2 berikut:

Tabel 2. Skor Alternatif Jawaban

\begin{tabular}{ll}
\hline Pernyataan & \\
\hline Alternatif Jawaban & Skor \\
\hline Sangat Layak & 4 \\
\hline Layak & 3 \\
\hline Tidak Layak & 2 \\
\hline Sangat Tidak Layak & 1 \\
\hline
\end{tabular}

\section{HASIL DAN PEMBAHASAN}

Penelitian ini dilakukan bertujuan untuk mengembangkan suatu Lembar Kerja Siswa (LKS) berbasis model POE sebagai bahan ajar yang diuji tingkat kelayakannya. Pengembangan LKS berbasis model POE ini dibuat menggunakan model 4D, dengan model tersebut dihasilkan LKS yang baik dan layak digunakan. LKS yang dihasilkan diharapkan dapat digunakan oleh siswa dan guru sebagai bahan ajar dalam pembelajaran dan buku pegangan bagi siswa untuk belajar di luar jam pembelajaran. LKS harus mudah dipahami oleh siswa, sehingga siswa tidak merasa kesulitan dalam penggunaan LKS tersebut.

Tahap define merupakan tahap memperoleh informasi berkaiatan dengan produk yang akan dikembangkan dan mengidentifikasi permasalahan dalam pembelajaran yang mendasari pentingnya pengembangan Lembar Kerja Siswa (LKS) berbasis model POE bagi Kelas XI SMA yang terdiri dari tahap pertama adalah observasi yang meliputi bahan ajar yang digunakan dalam pembelajaran berupa handout, metode mengajar yang digunakan guru dalam pembelajaran yaitu ceramah, Tanya jawab, dan pemberian tugas, dan sikap siswa dalam proses pembelajaran kurang aktif dalam menerima dn mencatat kembali penjelasan yang telah disampaikan.

Tahap design merupakan tahap pembuatan rancangan isi Lembar Kerja Siswa (LKS) dan pembuatan rancangan tampilan LKS. Rancangan LKS mempunyai tiga bagian utama yaitu bagian pendahuluan/pra isi, bagian inti/isi materi dan bagian penutup/pasca isi.

Tahap develop merupakan tahap penilaian produk dari ahli materi dan ahli media. Saran dan masukan yang diberikan oleh ahli materi digunakan untuk memperbaiki LKS berbasis model POE sehingga hasil yang diperoleh sesuai dengan pandangan materi dan kemudian dikonsultasikan kembali untuk mendapatkan penilaian kelayakan dan persetujuan untuk penelitian.

Berdasarkan hasil penilaian kelayakan dari ahli materi dapat diamati bahwa rerata skor terendah dari ketiga aspek tersebut yaitu pada aspek kebenaran materi materi $(3,6)$. Materi pada sistem pencernaa dan pernapasan dapat ditambah dan dilengkapi sesuai dengan materi yang dibutuhkan pada silabus. Soal evaluasi bisa lebih dikembangkan dan diperbanyak yang diharapkan dapat melatih dan menambah kemampuan belajar siswa secara kognitif, afektif, dan psikomotorik.

Validasi ahli media dilakukan oleh satu orang dosen media pembelajaran. Saran dan masukan yang diberikan oleh ahli media digunakan untuk memperbaiki LKS sehingga 
hasil yang diperoleh sesuai dengan pandangan media dan kemudian dikonsultasikan kembali untuk mendapatkan penilaian kelayakan dan persetujuan untuk penelitian.

Hasil validasi LKS berbasis model POE oleh ahli media kemudian dianalisis menggunakan skala likert dengan rentang skor 1 sampai 4. Berdasarkan penilaian dari ahli media diperoleh nilai rata-rata jumlah skor dari aspek penampilan fisik sebesar 11 yang termasuk kategori layak dengan rerata skor 3,4, nilai rata-rata jumlah skor dari aspek kemudahan penggunaan sebesar 32 yang termasuk kategori layak dengan rerata skor 3,3, dan nilai rata-rata jumlah skor secara keseluruhan sebesar 43 yang termasuk kategori layak dengan rerata skor 3,33.

Berdasarkan hasil penilaian kelayakan dari ahli media dapat diamati bahwa rerata skor yang diperoleh dari kedua aspek tersebut sudah baik, tetapi tidak menutup kemungkinan untuk meningkatkan kualitas LKS yang dikembangkan.

\section{SIMPULAN DAN SARAN}

Pengembangan LKS berbasis model Predict Observasi Explain (POE) kelas XI SMA melalui tahap Define, Design, Develop dan Disemination. Hasil penilaian kelayakan LKS berbasis model POE oleh ahli materi secara keseluruhan mendapatkan jumlah ratarata skor 41,5 dengan rerata skor 3,3 yang termasuk kategori "Layak". Penilaian kelayakan oleh ahli media mendapatkan jumlah rata-rata sk or 43 dengan rerata skor 3,3 yang termasuk kategori " Layak". Sehingga dapat disimpulkan bawah pengembangan LKS berbasis model POE "Layak" digunakan sebagai bahan ajar untuk SMA kelas XI.

Penelitian yang dilakukan tidak terlepas dari keterbatasan peneliti maka disusunlah saran sebagai berikut yaitu perlu adanya komunikasi yang lebih baik antara peneliti dengan pihak sekolah terutama guru pengampu mata pelajaran dalam menentukan materi yang hendak disusun dan penelitian pengembangan LKS sebaiknya dilanjutkan hingga tahap efektivitas LKS untuk mengetahui peningkatan hasil belajar siswa sehingga kemanfaatan LKS lebih nyata.

\section{RUJUKAN}

Arikunto, S. (2010). Prosedur Penelitian (Suatu Pendekatan Praktik). Jakarta: PT Rineka Cipta

Borg, D.W., Gall, Joyce., and Gall, Meredith D. (2003). Educational Research An Introduction. Boston: Pearson Education, Inc.

Dimyati \& Mudjiono. (2002). Belajar dan Pembelajaran. Jakarta: DPDIKBUD. ejournal.kopertais4.or.id/matar aman/index.php/washatiya/article/d ownload/.../2258/

Endang, Mulyatiningsih. (2013). Metode Penelitian Terapan Bidang Pendidikan. Bandung: ALFABETA

Liew, C.W. (2004). The effectivenees of Predict-Observe-Explain Technique in iagnosing Students' Understanding of science and Identifying Their Level of Achievement Curtin University of Technology. Science of Mathematics Education Centre.

Sanjaya, W. (2008). Perencanaan dan desain sistem pembelajaran. Jakarta: Kencana.

Sugiyono. (2013). Metode penelitian pendidikan pendekatan kuantitatif, kualitatif dan $R \& D$. Bandung: Alfabeta.

Sukmadinata dan Syaodih, N. , (2011). Metode Penelitian Pendidikan. Bandung: PT Remaja Rosdakarya.

Thiagarajan, S. Semmel, D. S \& Semmel, M. I. (1974) Instructional Development for Training Teachers of expectional Children. Minneapolis, minnesota: Leadership Training Institut/Special Education, University of minnesota. 